Jurnal Analis Kebijakan | Vol. 1 No. 2 Tahun 2017

\title{
REHABILITASI SOSIAL KORBAN PENYALAHGUNAAN NARKOTIKA MELALUI INSTITUSI PENERIMA WAJIB LAPOR (IPWL)
}

\section{SOCIAL REHABILITATION FOR NARCOTICS VICTIMS THROUGH REHABILITATION INSTITUTIONS (IPWL)}

\author{
Ahmad Shobirin \\ Biro Perencanaan Kementerian Sosial RI
}

\begin{abstract}
Abstrak
Permasalahan penyalahgunaan Narkotika di Indonesia semakin meningkat meskipun penindakan oleh aparat hukum dan keamanan telah dilaksanakan secara represif maupun persuasif. Diperlukan upaya atau pendekatan lain yaitu kuratif atau rehabilitasi, baik medis maupun sosial. Undang-Undang Nomor 35 tahun 2009 tentang Narkotika, dan PP Nomor 25 tahun 2011 tentang Pelaksanaan Wajib Lapor mengedepankan perlunya merehabilitasi pengguna Narkotika melalui Institusi Penerima Wajib Lapor (IPWL). Pada tahun 2015 Pemerintah menyatakan Indonesia dalam kondisi "Darurat Narkoba" dan berkomitmen untuk merehabilitasi 100.000 pengguna Narkotika di IPWL. Mandat ini perlu disikapi melalui optimalisasi dan dukungan terhadap IPWL, baik dari segi regulasi, SDM, budgeting, dan keberpihakan kebijakan. Kajian di enam provinsi terpilih terhadap pelaksanaan rehabilitasi sosial pengguna Narkotika melalui IPWL menunjukkan masih perlunya perbaikan sistem dan mekanisme kerja pelayanan dan sosialisasi serta beberapa perbaikan lainya. Melalui analisis SWOPA, disusun rekomendasi kebijakan yang diusulkan untuk memperbaiki sistem rehabilitasi dalam rangka menekan pengguna maupun kasus peredaran Narkotika di Indonesia, yaitu: 1) Peningkatan infrastruktur dan sarana prasarana lembaga IPWL; 2) Peningkatan kapasitas SDM pelaksana rehabilitasi sosial penyalahguna Narkotika di IPWL; dan 3) Memperkuat sinergitas antar kementerian/lembaga dalam pelaksanaan rehabilitasi sosial korban Narkotika melalui IPWL.
\end{abstract}

Kata kunci : Narkotika, rehabilitasi sosial, Institusi Penerima Wajib Lapor (IPWL)

\begin{abstract}
The problem of Narcotics abuse in Indonesia has been increasing even though law enforcements have been implemented through repressive and persuasive approaches. In addition to these approaches, curative or rehabilitation, both medical and social approaches, are important to tackle the problems. Law Number 35 of 2009 concerning Narcotics, and Government Regulation on Obligation Reports emphasizes the need to rehabilitate narcotics users through the rehabilitation institutions (IPWL). In 2015 the Government announced that Indonesia has reached 'State of Drugs Emergency", and Government is committed to rehabilitate 100,000 Narcotics users in IPWL. This mandate needs to be addressed through the optimization and support of IPWL, both in terms of regulation, human resources, budgeting, and policy alignments. Studies in six selected provinces on the implementation of social rehabilitation of Narcotics users through IPWL indicates that there is urgency to improve the rehabilitation system and working mechanism. Furthermore, better socialization is important for the rehabilitation issues. Through the SWOPA Analysis, policy recommendation is proposed to improve the rehabilitation system in order to suppress the number of users and cases of Narcotics circulation in Indonesia. It includes: 1) Infrastructure improvement and infrastructure facility of IPWL institution; 2) Improvement of human resource capacity for social rehabilitation of Narcotics abuse in IPWL; and 3) Strengthening
\end{abstract}


synergy between Ministries/Agencies in the implementation of social rehabilitation for Narcotics victims through IPWL.

Keywords: Narcotics, social rehabilitation, Reporting Recipient Institution (IPWL)

\section{A. Pendahuluan}

Kompleksitas permasalahan penyalahgunaan Narkotika di Indonesia semakin meningkat baik dari segi kuantitas, kualitas, dan eskalasi penyebarannya. Dari segi kuantitas, peningkatan ini dapat dilihat dari jumlah dan jenis Narkotika yang beredar, diperdagangkan atau diselundupkan masuk ke Indonesia. Dari segi kualitasnya, zat yang terkandung di dalam Narkotika telah bermutasi dan berkembang sedemikian rupa sehingga banyak Narkotika yang nonkonvensional yang saat ini bermunculan atau jenis Narkotika psikoaktif baru (new psychoactive substance, NPS), yang meningkat dari 166 jenis di tahun 2009 menjadi 251 jenis di pertengahan tahun 2011. Dari jumlah NPS tersebut, 38 diantaranya sudah masuk ke Indonesia

Sedangkan dari aspek eskalasi penyebarannya, saat ini dapat dikatakan bahwa hampir seluruh wilayah di Indonesia tidak steril dari Narkotika. Bahkan BNN mensinyalir bahwa seluruh wilayah kecamatan di Indonesia telah beredar Narkotika termasuk penggunanya. Selain tingkat penyebaran, profil pengguna Narkotika saat ini juga semakin beragam, tidak hanya didominasi oleh kalangan remaja dan dewasa, tapi juga anak-anak di bawah umur. Selain itu Narkotika juga digunakan oleh beragam profesi dengan latar belakang ekonomi dan sosial yang juga bervariasi. Dari segi penegakan hukum, jumlah kasus penyalahgunaan Narkotika baik di Jakarta maupun di beberapa daerah juga semakin meningkat. Selain itu aparat kepolisian dan BNN juga sering melakukan operasi penindakan kasus penyelundupan Narkotika dari luar negeri ke beberapa wilayah pesisir di Indonesia. Dari aspek penegakan hukum, pada tahun 2014 jumlah penghuni lapas sebanyak
159.882 orang, sekitar 50\% (95.000 orang) adalah penyalahguna/pecandu Narkotika.

Dampak yang ditimbulkan dari pengaruh dan penggunaan Narkotika tidak hanya di rasakan oleh individu pengguna, tapi juga keluarga, lingkungan, masyarakat, dan negara pada umumnya. Selain itu penyalahgunaan Narkotika tidak hanya berdampak pada sektor keamanan, tapi juga aspek kesejahteraan sosial, kondisi kesehatan masyarakat, dan kehidupan ekonomi. Dampak terhadap keamanan negara adalah semakin banyaknya warga negara, terutama usia produktif yang menggunakan Narkotika, maka kemungkinan besar tingkat kerawanan dan kriminalitas semakin tinggi. Selain itu wilayah geografis Indonesia yang masih terdapat daerah terluar dan perbatasan, mengakibatkan rawan penyelundupan Narkotika oleh orang yang tidak bertanggung jawab. Dari aspek kesehatan, karena zat-zat yang terkandung dalam Narkotika dapat merusak anggota tubuh dan kesehatan, maka penyalahguna Narkotika termasuk dalam warga negara yang selalu membutuhkan layanan kesehatan. Seperti halnya bahaya merokok, maka biaya pengobatan dan perawatan akibat mengkonsumsi Narkotika juga sangat tinggi/mahal, sehingga berdampak pada kondisi ekonomi individu dan keluarganya.

Sedangkan dalam aspek sosial, sebagaimana dikemukakan oleh Dubois dan Miley (1992: 351) menyebutkan bahwa orang yang ketergantungan Narkotika memiliki ketidakberfungsian atau permasalahan fisik, masalah psiko-logis, dan masalah sosial. Dengan demikian pengaruh atau dampak yang ditimbulkan dari penyalahgunaan Narkotika oleh individu dan masyarakat terkait erat dengan kondisi kesejahteraan sosial individu pengguna dan keluarga serta lingkungannya. 
Menurunnya derajat kehidupan, ketidakmampuan memenuhi kebutuhan dan melaksanakan peran sesuai dengan status yang diemban, terganggunya pola-pola komunikasi yang berdampak pada ketidakharmonisan keluarga, serta terhambatnya pelaksanaan tugas-tugas kehidupan lainnya merupakan salah satu contoh pengaruh Narkotika terhadap aspek sosial. Kompleksitas permasalahan, meningkatnya kasus dan jumlah penyalahguna, luasnya dampak yang ditimbulkan dari peredaran dan penyalahgunaan Narkotika menjadikan Indonesia sebagai "Darurat Narkotika".

Permasalahan tersebut perlu direspon dengan penanganan yang bersifat preventif, penindakan, rehabilitatif/kuratif, maupun promotif (after care). Upaya-upaya yang harus dilakukan secara mendesak untuk penanganan permasalahan Narkotika, terutama pada aspek pencegahan dan penindakan diantaranya adalah koordinasi lintas sektor seperti koordinasi terkait yaitu BNN, Kepolisian RI, Jaksa Agung, Mahkamah Agung (MA) Kementerian Hukum dan Hak Azasi Manusia (Kemenkumham). Sedangkan dalam aspek rehabilitatif dan promotif adalah sinergi dan koordinasi antara Kementerian Kesehatan dan Kementerian Sosial, sebagaimana amanat pasal 54 Undang-Undang No. 35 tahun 2009 tentang Narkotika yang menyatakan bahwa "pecandu Narkotika dan korban penyalahgunaan Narkotika wajib menjalani rehabilitasi medis dan rehabilitasi sosial". Berdasarkan perubahan paradigma ini maka berkonsekuensi pada perubahan regulasi di mana pengguna Narkotika yang mau melaporkan kondisinya ke pihak lembaga tertentu yang ditunjuk sesuai dengan undang-undang, maka mereka tidak akan dikategorikan pelaku kriminal, tapi justru mendapatkan pelayanan rehabilitasi, baik medis maupun sosial.

Lembaga tersebut diatur dalam Peraturan Pemerintah RI Nomor 25 tahun 2011 tentang Pelaksanaan Wajib Lapor Pecandu Narkotika menyebutkan bahwa Institusi Penerima Wajib Lapor (IPWL) adalah lembaga resmi yang diakui pemerintah untuk menerima wajib lapor. Berdasarkan hal tersebut di atas, maka Kementerian Sosial pada tahun 2015 telah mengadakan kajian di enam provinsi tentang permasalahan terkait. Kajian bertujuan untuk mengetahui pelaksanaan sekaligus menyediakan alternatif dan rekomendasi bagi pengambil kebijakan dan pihak-pihak terkait dalam meningkatkan pengelolaan IPWL bagi pecandu dan korban penyalahgunaan Narkotika dengan pendekatan rehabilitasi sosial.

Berdasarkan uraian tersebut di atas, maka permasalahan pokok (problem statement) dari kajian ini adalah: Bagaimana pelaksanaan rehabilitasi sosial bagi korban penyalahgunaan Narkotika oleh Institusi Penerima Wajib Lapor (IPWL)? Berdasarkan pernyataan masalah tersebut, maka tujuan kajian ini untuk menjawab pertanyaan: 1) Bagaimana kebijakan rehabilitasi sosial bagi korban Narkotika melalui IPWL?; 2) Bagaimana gambaran potensi, peluang, tantangan, dan isu startegis dalam rehabilitasi sosial bagi korban Narkotika melalui IPWL?; dan 3) Bagaimana manfaat dan kerugian kebijakan rehabilitasi sosial bagi korban Narkotika melalui IPWL?

\section{B. Metode Penelitian}

Penelitian ini merupakan kajian empiris yang didasarkan pada permasalahan yang terjadi saat ini dan kepentingan untuk mengatasi kendala yang ditemui dalam pengelolaan IPWL di daerah. Pengungkapan temuan kajian dilakukan melalui proses deskripsi, analisis sistematis, faktual dan akurat tentang wajib lapor bagi penyalahguna Narkotika dan pelaksanaan rehabilitasi sosial korban Narkotika. Sesuai dengan hal tersebut maka jenis kajian ini adalah kajian deskriptif. Teknik pengumpulan datanya adalah Diskusi Kelompok Terfokus (Focus Group Discussion/ $F G D$ ), wawancara mendalam (in-depth inter-view), observasi dan studi dokumen- 
tasi. FGD dilaksanakan tahun 2015 di 6 (enam) Provinsi, yaitu: Sulawesi Tenggara, Riau, Jambi, Aceh, Jawa Timur, dan Kalimantan Barat. Sumber data dalam FGD maupun indepth interview adalah pihak-pihak terkait dalam pelaksanaan IPWL, antara lain: Dinas Sosial, BNN Provinsi, Dinas Kesehatan, Unit di Kepolisian Daerah yang menangani Narkotika, Petugas di Pengadilan Negeri atau Kejaksaan yang menangani keputusan tentang kasus Narkotika, IPWL, Pekerja Sosial dan Konselor Adiksi, pengguna Narkotika yang ditangani IPWL, dan orang tua/keluarga pengguna Narkotika.

\section{Pemahaman Teoritik dan Praktik Rehabilitasi Sosial Pecandu dan Penyalahgunaan Narkotika melalui IPWL}

Penggunaan Narkotika tidak hanya berdampak atau dirasakan oleh penggunanya, tapi juga masyarakat sekitar. S. Joewana (1989: 113) menyatakan bahwa gangguan penggunaan zat memberi dampak yang luas, tidak hanya fisik dan jiwa, namun menimbulkan dampak sosial bagi dirinya sendiri, lingkungan keluarga, maupun masyarakat pada umumnya. Oleh karena itu terapi terhadap komplikasi medik dan habilitasi mental emosional perlu diikuti rehabilitasi sosial, edukasional, vokasional, dan membangkitkan kembali kehidupan beragama. Rehabilitasi sosial merupakan bagian terintegrasi dari proses penyembuhan ketergantungan narkotika. Selanjutnya disebutkan bahwa rehabilitasi sosial meliputi segala usaha yang bertujuan memupuk, membimbing, dan meningkatkan rasa kesadaran dan tanggung jawab sosial bagi keluarganya dan masyarakat (Joewana, 1989: 113). Definisi ini merujuk pemahaman bahwa perawatan dalam rehabilitasi sosial lebih mengedepankan peran keluarga dan masyarakat. Dalam konteks perawatan, hal ini belum menunjukkan penekanan perawatan untuk pecandu dan korban
Narkotika itu sendiri, meski selama perawatan dan apalagi pasca pelayanan (after care) peran keluarga dan masyarakat sangat penting.

Hampir senada dengan pengertian di atas tentang perlunya integrasi korban dan penyalahguna Narkotika dengan masyarakat, Nitimihardo (2004: 183) menyebutkan bahwa "Rehabilitasi sosial merupakan upaya yang bertujuan untuk mengintegrasikan seseorang yang mengalami masalah sosial ke dalam kehidupan masyarakat di mana dia berada". Pengertian ini merujuk bahwa pemahaman pentingnya korban dan penyalahguna Narkotika untuk memiliki kehidupan normal di tengah masyarakat.

Pemahaman yang lebih komprehensif tentang rehabilitasi sosial ada pada UU Nomor 11 tahun 2009 tentang Kesejahteraan Sosial, yaitu "Proses refungsionalisasi dan pengembangan untuk memungkinkan seseorang mampu melaksanakan fungsi sosialnya secara wajar dalam kehidupan masyarakat". Fungsi sosial yang wajar bagi pecandu Napza dicirikan kemampuan mereka dalam memecahkan masalah, memenuhi kebutuhan, melaksanakan peran dan tugas-tugas kehidupan. Orang yang telah kecanduan Napza tidak dapat melaksanakan fungsi sosialnya dengan baik, sehingga mereka perlu mendapatkan rehabilitasi.

Rehabilitasi sosial dimaksudkan untuk memulihkan dan mengembangkan kemampuan seseorang yang mengalami disfungsi sosial agar dapat melaksanakan fungsi sosialnya secara wajar, dilaksanakan secara persuasif, motivatif, koersif, baik dalam keluarga, masyarakat maupun panti sosial, diberikan dalam bentuk : 1) motivasi dan diagnosis psikososial; 2) perawatan dan pengasuhan; 3) pelatihan vokasional dan pembinaan kewirausahaan; 4) bimbingan mental spiritual; 5) Bimbingan fisik; 6) bimbingan sosial dan konseling psikososial; 7) pelayanan aksesibilitas; 8) bantuan dan asistensi sosial; 
9) bimbingan resosialisasi; 10) bimbingan lanjut; dan/atau 11) rujukan.

Terkait dengan permasalahan penyalahgunaan Napza, di mana salah satu karateristiknya adalah bio-psikososial, maka dalam rehabilitasi sosial bagi korban Napza adalah intervensi yang holistik. Hal tersebut dikarenakan hakikat dari rehabilitasi sosial itu adalah interaksi, yaitu: saling ketergantungan dan saling berhubungan di antara dan antar banyak disiplin ilmu, pasien atau klien, keluarga, sumber yang dapat membantu atau mendukung komunitas dan pemerintah.

Dalam Undang-Undang Nomor 35 tahun 2009 tentang Narkotika, terkait dengan wajib lapor, pada pasal 55, pecandu Narkotika dibedakan menjadi: "di bawah umur" dan "cukup umur". Pasal 55 menyebutkan: ayat (1) Orang tua atau wali dari pecandu Narkotika yang belum cukup umur wajib melaporkan kepada pusat kesehatan masyarakat, rumah sakit, dan atau lembaga rehabilitasi medis dan atau lembaga rehabilitasi sosial yang ditunjuk oleh pemerintah untuk menda-patkan rehabilitasi medis dan rehabilitasi sosial. Ayat (2) dinyatakan, pecandu Narkotika yang sudah cukup umur wajib melaporkan diri atau dilaporkan keluarganya kepada pusat kesehatan masyarakat, rumah sakit, dan atau lembaga-lembaga rehabilitasi medis dan atau lembaga rehabilitasi sosial yang ditunjuk oleh pemerintah untuk mendapatkan rehabilitasi medis dan rehabilitasi sosial. Ayat 1 dan 2 tersebut terlihat ada kalimat "Wajib Lapor" sebagai kewajiban pecandu Narkotika untuk mendapatan pelayanan di IPWL.

Selain itu Surat Edaran Mahkamah Agung Nomor 3 tahun 2011 menyatakan bahwa seorang pecandu yang menjalani peradilan dapat ditempatkan dalam rehabilitasi medis atau sosial, yang di maksud dengan ini adalah di mana para korban penyalahgunaan Narkotika akan mendapatkan pelayanan medis dan bimbingan psikologi secara utuh dari orang-orang yang terlatih dan profesional di bidang ilmu kedokteran dan kejiwaan. Hal tersebut menunjukkan terobosan hukum yang sangat berarti bagi pecandu Narkotika. Kebijakan tersebut di atas merupakan program pemerintah yang memberikan tugas dan fungsinya kepada IPWL untuk para korban penyalahgunaan Narkotika.

Rehabilitasi sosial korban penyalahgunaan Narkotika dilaksanakan melalui IPWL dengan program di dalam (institutional-based) dan di luar (non-institutional-based) lembaga seperti kegiatan home care maupun day care. Intervensi rehabilitasi sosial melalui IPWL/LKS diawali dengan asesmen korban penyalahgunaan Narkotika. Rehabilitasi sosial melalui IPWL/LKS dilaksanakan dengan acuan pedoman rehabilitasi sosial, program intervensinya menggunakan pendekatan pekerjaan sosial, spiritual, medis, dan atau tradisional.

Untuk mengetahui kemajuan pemulihan korban penyalahgunaan Narkotika di IPWL dilakukan pembahasan kasus (case conference) untuk menentukan program pemulihan selanjutnya. Program dibuat bersama dengan korban penyalahgunaan Narkotika dan diarahkan oleh pekerja sosial dan atau konselor. Intervensi yang akan dilakukan harus melalui kontrak layanan yang disepakati untuk dilaksanakan oleh korban penyalahgunaan Narkotika, keluarga dan dipantau pendamping.

Pemulihan rumahan (home care) melibatkan keluarga, kawan, dan lingkungan yang dikenal korban penyalahgunaan Narkotika. Hal ini seringkali menyediakan lingkungan yang mendukung dalam rangka mencapai kesehatan mental/ spiritual, fisik, dan kemandirian. Sedangkan pemulihan harian (day care), kondisi korban penyalahgunaan Narkotika sudah memungkinkan untuk hadir pada pertemuan konseling kelompok dan atau konseling individu serta aktivitas yang dirancang untuk mendukung pemu- 
lihan yang dilaksanakan di lembaga. Korban penyalahgunaan Narkotika yang mengikuti rehabilitasi sosial korban penyalahgunaan Narkotika di IPWL/LKS dapat berasal dari rujukan (kepolisian, kejaksaan, dan pengadilan), serta warga masyarakat yang mempunyai kepedulian dalam menangani masalah penyalahgunaan Narkotika, dan atau orang tua/wali dari korban penyalahgunaan Narkotika.

Setelah dilakukan asesmen, dapat diketahui program dan kegiatan yang akan dilaksanakan berdasarkan berat, sedang atau ringannya permasalahan penyalahgunaan Narkotika yang dihadapi. Dari asesmen dituangkan dalam program atau rencana intervensi dibuat sesuai permasalahan yang dihadapi korban penyalahgunaan Narkotika, diperkuat dengan kontrak layanan antara korban penyalahgunaan Narkotika dengan konselor dan pekerja sosial yang mendampingi korban penyalahgunaan Narkotika tersebut.

Atas dasar asesmen terkait perkembangan pemulihan diperlukan program pemulihan lanjutan. Pelaksanaannya dapat dirancang dalam bentuk pemulihan rumahan, pemulihan harian dan rehabilitasi sosial dalam lembaga. Pada tahap resosialisasi ini merupakan tahap untuk mempersiapkan korban penyalahgunaan Narkotika kembali ke masyarakat. Laporan selama menjalankan rehabilitasi sosial korban penyalahgunaan Narkotika dilaksanakan secara berkala 2 (dua) bulan sekali dan rekapitulasi disampaikan kepada Badan Narkotika Nasional (BNN).

\section{Hasil Kajian Lapangan}

Permasalahan Narkotika tidak hanya berpengaruh pada individu pengguna/penyalahgunannya saja, tetapi juga terhadap keluarga, lingkungan sekitar, dan masyarakat luas. Dampak terhadap individu misalnya kondisi kesehatan dan mentalnya, kehidupan sosialnya terganggu, dan karir ataupun pendidikannya juga terancam putus. Dampak terhadap lingku- ngan misalnya keamanan dan kenyaman lingkungan terganggu karena tindakan pengguna Narkotika yang melanggar norma sosial dapat memicu keributan, melakukan tindakan kriminal, dan pelanggaran hukum lainnya. Hal ini membuktikan bahwa persoalan Narkotika berdimensi bio-psiko-sosial-spiritual. Luasnya pengaruh dan dampak yang timbul dari permasalahan penyalahgunaan Narkotika di Indonesia membuat Pemerintah menyatakan Indonesia sedang berada pada kondisi "Darurat Narkotika" sehingga membutuhkan strategi penanganan yang komprehensif dan terpadu yang menuntut keterlibatan berbagai instansi dan lintas sektor.

Hasil kajian melalui FGD di enam provinsi, teridentifikasi permasalahan kebijakan sebagai berikut:

1. Aspek Regulasi

Aspek regulasi terkait dengan beragamnya penafsiran dan implementasi di lapangan. Selain itu dalam regulasi masih banyak terdapat aspekaspek hukum yang perlu diperbaiki. Temuan terhadap aspek regulasi ini antara lain :

a. Masih terdapat ketentuan yang dilanggar dalam Peraturan Bersama (PerBer) 7 (tujuh) Kementerian/ Lembaga tentang Penanganan Pecandu Narkotika dan Korban Penyalahgunaan Narkotika ke dalam Lembaga Rehabilitasi, di mana seharusnya tidak ada penangkapan sepanjang pecandu diputus untuk mengikuti rehabilitasi. Namun dalam kenyataannya tetap terjadi penangkapan.

b. Ada beberapa ketentuan pada pasalpasal dalam regulasi penanganan narkotika yang tidak saling sinergi/ menunjang, misalnya: UndangUndang No. 35 tahun 2009 (pasal 111, 112, 114, 127) dengan Surat Edaran Mahkamah Agung RI No. 04 tahun 2010 (poin B). 
c. Belum adanya aturan yang konkrit tentang IPWL di daerah terkait dengan kebijakan Pemda mengenai IPWL.

d. Tidak adanya pekerja sosial atau petugas dari Dinas Sosial dalam tim asesmen sebagaimana terdapat dalam Peraturan Bersama mengakibatkan kekhawatiran kesalahan identifikasi dan diagnosa.

e. Dalam Petunjuk Teknis (Juknis) sebagai jabaran dari Surat Edaran Bersama tersebut tidak terdapat profesi pekerja sosial sebagai tim asesmen atau saksi ahli. Atau secara kelembagaan hanya melibatkan BNN, Polisi, Kemenkes, dan Kejaksaan. Profesi yang dilibatkan adalah psikolog, dokter, dan tim dari penegak hukum. Oleh karena itu Juknis tersebut perlu dilakukan revisi.

f. Masih berbedanya pemahaman tentang keberadaan IPWL sebagai tempat untuk melapor, atau sebagai tempat rehabilitasi. Selain itu apakah rehabilitasi di dalam lembaga (institutional based), atau rawat jalan.

\section{Aspek Sosialisasi}

Sosialisasi merupakan tahapan kegiatan yang ditujukan untuk memberikan pengetahuan, dan pemahaman masyarakat tentang regulasi yang terkait dengan penanganan Narkotika di Indonesia, termasuk regulasi tentang IPWL bagi korban Narkotika. Permasalahan yang terkait dengan aspek sosialisasi adalah:

a. Sosialisasi belum dilaksanakan secara luas dan langsung kepada sasaran atau obyek yang dituju, yaitu pengguna dan penyalahguna Narkotika, termasuk orang tua (keluarga), dan lingkungan masyarakat.

b. Masih banyak aparat pemerintahan di daerah dan pihak keamanan yang juga belum memahami tentang regulasi penanganan Narkotika.

c. Pemahaman tentang Wajib Lapor masih dipahami beragam, baik oleh kepolisian, pengadilan BNN, pengguna/penyalahguna Narkotika dan keluarganya, maupun masyarakat.

\section{Aspek Koordinasi}

Koordinasi terkait dengan keterpaduan lembaga (LKS), instansi pemerintah atau SKPD dan pelaksanaan kegiatan rehabilitasi Narkotika di daerah:

a. Masing-masing IPWL di daerah melaksanakan kegiatan yang berdiri sendiri sesuai dengan penekanan tugas dan fungsi masing-masing.

b. IPWL kurang berkoordinasi dengan Pemerintah Daerah, sehingga keberadaan mereka tidak diketahui oleh SKPD terkait.

c. Seleksi petugas pelaksana dan LKS yang akan ditetapkan sebagai IPWL kurang melibatkan pemerintah daerah/ SKPD terkait.

\section{Aspek Sumber Daya Manusia}

Sumber daya manusia pelaksana IPWL adalah para pekerja sosial (peksos) adiksi dan konselor adiksi yang telah mengikuti tahapan seleksi dan penetapan serta pelatihan. Secara umum kondisi SDM tersebut antara lain:

a. Jumlah peksos adiksi dan konselor adiksi masih terbatas.

b. Komitmen pelaksanaan tugas masih perlu ditingkatkan. Bahkan dibandingkan dengan petugas yang bekerja di IPWL yang tidak termasuk peksos dan konselor adiksi, kinerja mereka masih jauh dari target kinerja yang diharapkan.

c. Latar belakang pendidikan beragam, atau tidak berlatar belakang pendidikan pekerjaan/ kesejahteraan sosial. Dengan demikian akan berpengaruh pada efekti- 
fitas dan ketepatan pelaksanaan tugas-tugas rehabilitasi.

\section{Aspek Kelembagaan}

Kelembagaan adalah lembaga kesejahteraan sosial yang memenuhi kriteria dan ditetapkan sebagai IPWL Kementerian Sosial. Kondisi kelembagaan sebagai berikut:

a. Kondisi sarana prasarana rehabilitasi umumnya masih terbatas dan belum sesuai dengan standar LKS pelaksana IPWL.

b. Masih terdapat sumber pendanaan APBN yang ganda diterima oleh IPWL, yaitu dari Kementerian Sosial dan BNN.

c. Kegiatan rehabilitasi di lembaga masih menggunakan metode tradisional murni dan perpaduan antara model keagamaan dengan pekerjaan sosial/ kesejahteraan sosial.

d. Aspek Perencanaan dalam penanganan dan rehabilitasi Narkotika oleh lembaga belum terlaksana dengan baik.

\section{Aspek Tata laksana}

Tata laksana terkait dengan pengelolaan program IPWL secara keseluruhan. Temuan pada aspek tata laksana, antara lain:
a. Standar Operasional Prosedur (SOP) terkait dengan tahapan pelayanan belum ada.
b. Materi pelatihan dalam rangka meningkatkan kapasitas pelaksana kurang memadai dan tidak sesuai dengan yang dibutuhkan (terlalu teoritis, kurang aplikatif).
c. Penetapan pekerja sosial dan konselor adiksi tidak sesuai dengan kriteria yang telah ditetapkan tidak sesuai dengan kriteria yang telah ditetapkan.
d. Penetapan LKS sebagai IPWL

e. Prosedur pencairan anggaran sesuai perencanaan kebutuhan tidak berjalan dengan baik.

\section{E. Rekomendasi Kebijakan}

Dalam mengajukan rekomendasi kebijakan perlu memperhatikan lingkungan kebijakan internal dan eksternal yang mempengaruhi kebijakan IPWL, yaitu:

1. Lingkungan internal: a) Keterbatasan kuantitas dan kualitas SDM pelaksana rehabilitasi dan LKS yang ditetapkan menjadi IPWL, b) Mekanisme dan sistem pengembangan kapasitas yang belum maksimal, misalnya pola pengembangan kediklatan tidak sesuai kebutuhan, peningkatan sarana prasarana dan infrastruktur rehabilitasi belum memadai, c) aspek perencanaan dan keberlanjutan program dengan memperhatikan stakeholder mapping lembaga terkait.

2. Lingkungan eksternal: Aturan pelaksanaan dalam peraturan perundangundangan yang ada belum mengakomodir pendekatan rehabilitasi sosial dan pekerjaan sosial, yaitu a) Profesi pekerja sosial tidak ada dalam Tim Asesmen sebagaimana terdapat dalam Peraturan Bersama 7 (tujuh) Kementerian/Lembaga dalam penanganan Narkotika; b) Pemahaman tentang Wajib Lapor masih dipahami beragam, baik oleh kepolisian, pengadilan, BNN, pengguna/penyalahguna Narkotika dan keluarganya, maupun masyarakat; c) Terdapat beberapa ketentuan pada pasal-pasal dalam regulasi penanganan narkotika yang tidak saling sinergi/ menunjang.

Dari kedua lingkungan kebijakan tersebut, dan memperhatikan prioritas dan kemungkinan dapat dilakukannya perbaikan kebijakan, maka perlu rekomendasi kebijakan yang diusulkan yaitu :

1. Peningkatan infrastruktur dan sarana prasarana Lembaga IPWL; 
2. Peningkatan kapasitas SDM pelaksana rehabilitasi sosial penyalahguna Narkotika di IPWL;

3. Memperkuat sinergitas antar Kementerian/Lembaga dalam pelaksanaan rehabilitasi sosial korban Narkotika melalui IPWL.

Dari ketiga usulan kebijakan tersebut selanjutnya dilakukan analisis melalui metode analisis SWOPA, yaitu mengukur alternatif kebijakan dari segi kekuatan (strength), kelemahan (weakness), peluang (opportunity), masalah (problem) dan tindakan (action).

Kekuatan, merupakan keunggulan kebijakan dilihat dari dampaknya terhadap kehidupan penyalahguna Narkotika, termasuk keluarga, dan lingkungan; bagaimana dukungan publik terhadap kebijakan, dan beban anggaran yang tersedia dan dibutuhkan untuk implementasi kebijakan, termasuk dukungan anggaran. Kelemahan merupakan kekurangan kebijakan dilihat dari alternatif yang ditawarkan seperti beban anggaran yang besar, kurang menarik atau tidak mendapatkan dukungan secara politis, dan kelembagaan pelaksanaan yang kurang dipersiapkan.

Peluang, melihat kesempatan/ peluang yang muncul dari lingkungan eksternal yang akan mendukung diterimanya kebijakan sesuai dengan Political agenda (kebijakan Pemerintah sesuai Nawacita dan RPJMN 2014-2019); National Issues, (perhatian publik terhadap isu kualitas SDM/investasi sosial, penegakan hukum/good governance); International Trend (dukungan internasional dan Isu global, misalnya dalam kaitan dengan isu Millenium Development Goals (MDGs) atau Sustainable Development Goals (SDG). Sedangkan masalah (problem), merupakan sekumpulan persoalan apa yang mungkin menghambat diterimanya kebijakan oleh policy audience dilihat dari alternatif yang ditawarkan.

Tindakan (Action), tindakan atau langkah apa yang dapat atau perlu dilakukan untuk mengatasi kelemahan dan masalah dari masing-masing alternatif kebijakan. Penilaian kelayakan mencakup apakah kebijakan ini realistis atau imajinatif, sulit untuk diimplementasikan. Pertanyaannya apakah tindakan yang dilakukan akan mencapai tujuan dan sasaran yang ingin dicapai, sesuai atau tidak besaran tindakan sebagai solusi dengan target masalah yang akan dipecahkan.

Untuk memperjelas penggunaan metode SWOPA dalam menganalisis alternatif rekomendasi kebijakan yang ditawarkan, dijabarkan dalam Matrik 1 berikut ini.

\section{Matrik 1 \\ Perbandingan Rekomendasi Kebijakan Berdasarkan Analisis SWOPA}

\begin{tabular}{|c|c|c|c|c|}
\hline No. & : & $\begin{array}{c}\text { Peningkatan Infrasruktur dan } \\
\text { Sarana Prasarana Lembaga } \\
\text { IPWL }\end{array}$ & $\begin{array}{c}\text { Peningkatan Kapasitas SDM Pelaksana } \\
\text { Rehabilitasi Sosial penyalahguna Narkotika } \\
\text { di IPWL }\end{array}$ & $\begin{array}{l}\text { Memperkuat Sinergitas Antar } \\
\text { Lembaga Pemerintah dalam } \\
\text { Pelaksanaan Rehabilitasi Sosial } \\
\text { Korban Narkotika melalui IPW'L }\end{array}$ \\
\hline 01 & 02 & 03 & $\overline{05}$ & 04 \\
\hline 1 & 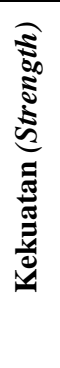 & $\begin{array}{l}\text { - Dukungan legalitas: UU No. } 11 \\
\text { tahun } 2009 \text { tentang Kesos } \\
\text { - Dukungan legalitas : UU } 25 \text { tahun } \\
2009 \text { tentang Narkotika } \\
\text { - UU } 23 \text { tahun } 2014 \text { yang } \\
\text { menempatkan penangangan } \\
\text { Narkotika menjadi tanggung } \\
\text { jawab pemerintah pusat } \\
\text { - Permensos No. 03 tahun } 2013 \\
\text { tentang Standar Lembaga }\end{array}$ & $\begin{array}{l}\text { - Dukungan legalitas: UU No. } 11 \text { tahun } 2009 \\
\text { tentang Kesos } \\
\text { - Dukungan legalitas : UU } 25 \text { tahun } 2009 \\
\text { tentang Narkotika } \\
\text { - Peran pendamping cukup kuat sekaligus } \\
\text { meningkatkan SDM berbasis pekerja sosial } \\
\text { professional } \\
\text { - Peraturan Menteri Sosial No. } 16 \text { tahun } 2012 \\
\text { tentang Sertifikasi Pekerja Sosial Profesional } \\
\text { dan Tenaga Kesejahteraan Sosial }\end{array}$ & $\begin{array}{l}\text { - Dukungan legalitas: UU No. } 11 \\
\text { tahun } 2009 \text { tentang Kesos } \\
\text { - Dukungan legalitas : UU No. } 25 \\
\text { tahun } 2009 \text { tentang Narkotika } \\
\text { - Bermatra makro, dan menyentuh } \\
\text { aspek kebijakan hulu }\end{array}$ \\
\hline
\end{tabular}




\begin{tabular}{|c|c|c|c|c|}
\hline No. & 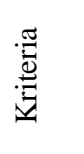 & $\begin{array}{c}\text { Peningkatan Infrasruktur dan } \\
\text { Sarana Prasarana Lembaga } \\
\text { IPWL }\end{array}$ & $\begin{array}{c}\text { Peningkatan Kapasitas SDM Pelaksana } \\
\text { Rehabilitasi Sosial penyalahguna Narkotika } \\
\text { di IPWL }\end{array}$ & $\begin{array}{l}\text { Memperkuat Sinergitas Antar } \\
\text { Lembaga Pemerintah dalam } \\
\text { Pelaksanaan Rehabilitasi Sosial } \\
\text { Korban Narkotika melalui IPW'L }\end{array}$ \\
\hline \multirow[t]{2}{*}{01} & 02 & 03 & 05 & 04 \\
\hline & & $\begin{array}{l}\text { Rehabilitasi Sosial Korban } \\
\text { Penyalahguna Narkotika } \\
\text { - Peraturan Menteri Sosial No. } 17 \\
\text { Tahun } 2012 \text { tentang Akreditasi } \\
\text { Lembaga Kesejahteraan Sosial } \\
\text { - Sub agenda nomor } 4 \text { Nawa Cita: } \\
\text { Pemberantasan penyalahgunaan } \\
\text { Narkotika dan psikotropika, } \\
\text { dengan strategi Penguatan } \\
\text { lembaga terapi dan rehabilitasi }\end{array}$ & & \\
\hline 2 & 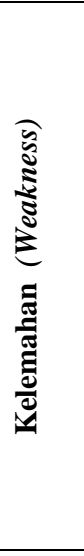 & $\begin{array}{l}\text { - Konstruksi dan keberlanjutan } \\
\text { anggaran (tahun } 2015 \text { masih } \\
\text { melalui APBN Perubahan) } \\
\text { - Kualitas dan kuantitas lembaga } \\
\text { rehabilitasi sosial korban } \\
\text { Narkotika masih terbatas } \\
\text { - Tergantung penuh pada komitmen } \\
\text { "pemimpin"/ pengurus yayasan/ } \\
\text { lembaga rehabilitasi }\end{array}$ & $\begin{array}{l}\text { - Profesi Pekerja Sosial tidak masuk dalam Tim } \\
\text { Asesment Terpadu (TAT) dalam } \\
\text { mempertimbangkan tindak lanjut perawatan } \\
\text { pecandu Narkotika sebagaimana terdapat } \\
\text { dalam PerBer } 2014 \text { tentang "Penanganan } \\
\text { Pecandu Narkotika dan Korban } \\
\text { Penyalahgunaan Narkotika ke dalam } \\
\text { Lembaga Rehabilitasi" } \\
\text { - Komitmen pekerja sosial adiksi dan konselor } \\
\text { adiksi terhadap tugas dan tanggung jawab } \\
\text { dalam melaksanakan perannyabelum sesuai } \\
\text { harapan } \\
\text { - Kondisi eksisting peksos dan konselor adiksi, } \\
\text { tidak semua berlatar belakang pendidikan } \\
\text { pekerjaan/ kesejahteraan sosial } \\
\end{array}$ & $\begin{array}{l}\text { - Beban anggaran yang relatif besar } \\
\text { - Rentang kendali yang terlalu } \\
\text { panjang }\end{array}$ \\
\hline 3 & 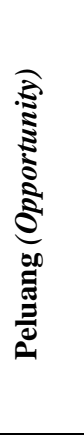 & $\begin{array}{l}\text { - Meningkatkan kuantitas dan } \\
\text { kualitas kelembagaan IPWL } \\
\text { Kemensos sesuai Permensos No. } \\
\text { 03 tahun } 2012 \text { Standar Lembaga } \\
\text { Rehabilitasi Sosial Korban } \\
\text { Penyalahgunaan Narkotika }\end{array}$ & $\begin{array}{l}\text { - Positioning peksos dan konselor adiksi } \\
\text { berlatar belakang profesi pekerjaan sosial dan } \\
\text { atau kompetensi pekerjaan sosial dalam } \\
\text { tugas-tugas rehabilitasi sosial di LKS } \\
\text { - Peksos dan Konselor Adiksi sebagai front line } \\
\text { worker mampu menunjukkan kiprah di } \\
\text { masyarakat dalam rangka pengakuan dan } \\
\text { eksistensi profesi } \\
\text { - Memberikan penekanan pada rehabilitasi } \\
\text { sosial sesuai dengan tahapan dan metoda } \\
\text { intervensi pekerjaan/ kesejahteraan sosial } \\
\text { profesional }\end{array}$ & $\begin{array}{l}\text { - Lampiran UU } 23 \text { tahun } 2014 \\
\text { tentang Pemerintahan Daerah } \\
\text { menempatkan urusan } \\
\text { penanganan korban Narkotika } \\
\text { (dan orang dengan HIV/AIDS) } \\
\text { menjadi kewenangan pemerintah } \\
\text { pusat } \\
\text { Komitmen pemerintah : } \\
\text { "Indonesia Darurat Narkoba" }\end{array}$ \\
\hline 4 & 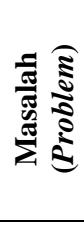 & $\begin{array}{l}\text { - Permasalahan Sarana dan } \\
\text { prasarana yang dimiliki } \\
\text { penyelenggara rehabilitasi masih } \\
\text { belum mencukupi bila dibanding } \\
\text { dengan yang dilayani }\end{array}$ & $\begin{array}{l}\text { - Materi diklat peningkatan kapasitas belum } \\
\text { terstandar/ belum memenuhi kebutuhan } \\
\text { - Kualitas dan kuantitas peksos dan konselor } \\
\text { adiksi yang terbatas } \\
\text { - Komitmen peksos dan konselor adiksi masih } \\
\text { perlu diperkuat }\end{array}$ & $\begin{array}{l}\text { - Perbedaan kewenangan dan target } \\
\text { antara kementerian/ lembaga } \\
\text { - Masih adanya ego sektoral masing- } \\
\text { masing stakeholder } \\
\text { - Kurangnya keterlibatan aparatur di } \\
\text { daerah }\end{array}$ \\
\hline 5 & 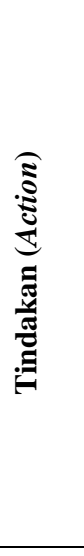 & $\begin{array}{l}\text { - Penetapan lembaga rehabilitasi } \\
\text { sosial pelaksana IPWL sesuai } \\
\text { dengan standar } \\
\text { - Penganggaran sesuai dengan } \\
\text { perencanaan } \\
\text { - Pemenuhan kebutuhan sarana } \\
\text { prasarana rehabilitasi }\end{array}$ & $\begin{array}{l}\text { - Pelatihan dan peningkatan kapasitas SDM } \\
\text { IPWL sesuai standar } \\
\text { - Pendidikan dan Pelatihan peksos dan konselor } \\
\text { adiksi secara regular, terutama yang tidak } \\
\text { berlatar belakang pendidikan pekerjaan/ } \\
\text { kesejahteraan sosial. } \\
\text { - Bimbingan dan Pemantapan (Bimtap) serta } \\
\text { dan TOT petugas } \\
\text { - Sertifikasi profesi kepada pekerja adiksi } \\
\text { - Perencanaan man power planning dan } \\
\text { keberlanjutan terkait dengan program dan } \\
\text { kelembagaan IPWL }\end{array}$ & $\begin{array}{l}\text { - Memperkuat peran dan fungsi } \\
\text { masing-masing pihak sesuai dengan } \\
\text { Peraturan Bersama (PerBer) tahun } \\
2014 \text { tentang Penanganan pecandu } \\
\text { Narkotika dan Korban } \\
\text { Penyalahgunaan Narkotika ke } \\
\text { dalam lembaga Rehabilitasi } \\
\text { - Melaksanakan Forum konsultasi } \\
\text { dan evaluasi periodik sesuai dengan } \\
\text { peran dan fungsi kementerian } \\
\text { lembaga yang diamanatkan dalam } \\
\text { PerBer } \\
\text { - Implementasi Peraturan Bersama } \\
\text { sesuai dengan kewenangannya } \\
\text { masing-masing }\end{array}$ \\
\hline
\end{tabular}




\section{F. Penutup}

Permasalahan Narkotika di Indonesia perlu penanganan yang komprehensif, berkelanjutan, dan terpadu antar pihak, yaitu keterpaduan dalam pencegahan, penindakan, rehabilitasi, dan pasca rehabilitasi (after care). Oleh karenanya pendekatan keamanan dan penindakan hukum perlu diimbangi dengan aspek kuratif dan promotif bagi korban Narkotika yang telah mengikuti perawatan. Oleh karena itu, paradigma tersebut perlu diimbangi dengan cara pandang yang lain, di mana para pecandu Narkotika harus diberikan terapi dan rehabilitasi, baik sosial maupun medis, untuk mengatasi kecanduannya.

Undang-Undang Nomor 35 tahun 2009 tentang Narkotika memberikan penekanan yang sangat jelas bahwa pecandu Narkotika perlu direhabilitasi. Salah satu pintu masuknya adalah melalui kerelaan mereka melaporkan keadaan atau permasalahan ketergantungan Narkotika, yaitu melalui Wajib Lapor. Kewajiban ini perlu dilakukan oleh pecandu agar mereka mendapatkan rehabilitasi di IPWL.

\section{Daftar Pustaka}

Dubois, Brenda, dan Miley K.K., $5^{\text {th }}$ Ed, 1992, Sosial Work : An Empowering Profession, New York : Pearson
Satya, Joewena, 1989, Gangguan Penggunaan Zat Narkotika, Alkohol, dan Zat Adiktif lainnya, Jakarta : PT Gramedia

Nitimiharjo, Carolina, 2004, Isu-Isu Tematik Pembangunan Sosial : Konsepsi dan Strategi, Jakarta : Badan Diklat dan Pengembangan Sosial Departemen Sosial

Alie, Faried dan Syamsu Alam, Andi, 2012, Studi Kebijakan Pemerintah, Bandung : Refika Aditama

Nawawi, Hadari, 2000, Metoda Penelitian Bidang Sosial. Yogyakarta : Gajah Mada University Press

Nugroho, Riant, Kebijakan Publik, 2008, Jakarta : Penerbit PT Elex Media Kumputindo Kelompok Gramedia

Nugroho, Riant, 2014, Metoda Penelitian Kebijakan, Yogyakarta : Pustaka Pelajar

\section{$\underline{\text { Peraturan Perundangan }}$}

Undang-Undang RI Nomor 11 tahun 2009 tentang Kesejahteraan Sosial

Undang-Undang RI Nomor 25 tahun 2009 tentang Narkotika

Peraturan Pemerintah Nomor 25 tahun 2011 tentang Pelaksanaan Wajib Lapor Pecandu Narkotika

Peraturan Bersama (PerBer) tahun 2014 tentang Penanganan Pecandu Narkotika dan Korban Penyalahgunaan Narkotika ke dalam Lembaga Rehabilitasi 